\title{
Interreligious Dialogue: A Case Study Approach in Respect to the Vatican and the World Council of Churches
}

\author{
Douglas Pratt
}

Interreligious dialogue and the promotion of interfaith relations is a feature of our times. During the twentieth century, global Christianity-as represented in an ecumenical sense by the Vatican and World Council of Churches (wCC) reached a position wherein, initially, interreligious dialogue, subsequently also 'interfaith relations' to reflect a broader scope and agenda, became affirmed and embraced. This has been in no small measure due to the rising influence of Asian and African Christian leadership and engagement during the 2oth century in respect of both the Vatican (e.g. Cardinal Francis Arinze) and the wCC (e.g. M.M. Thomas, Paul Devanandan, Wesley Ariarajah).

In recent decades the term 'World Christianity' has come into vogue, almost eclipsing the term 'ecumenical Christianity' as the referent for world-wide Christianity. Whereas ecumenism — or the ecumenical movement_arose out of early 2oth century ecclesial motivations to address questions of Christian mission and unity, the relative innovation of the 'World Christianity' appellation tends to transcend even the inclusiveness of ecumenism, at least in terms of institutional expression. It highlights the transcendental character of catholicity - that urgrund inclusivity that is a mark of what it means to be 'members one of another'. All Christians everywhere, together form one vast global community, at least in some ideal sense. It is more than ecclesia; it finds a parallel in the Islamic notion of Muslims forming a single ummah.

Building on Henry van Dusen's conceptualisation of World Christianity as a quest to promote Christian mission and unity (Robert 2009), this contribution considers World Christianity to indicate this consciousness of belonging to a worldwide Christian oikoumene and sees the World Council of Churches and the Vatican, being "two extensive networks that knit together Christians from various parts of the world" (Cabrita and Maxwell 2017: 31), as key institutions that promote such a consciousness. Within this Christian oikumene there has been an increasing consciousness about 'the religious other' and about the 
need to reflect on the encounter with people of other faith traditions, highlighted by scholars such as Peter Phan and Dale Irvin who define their research as studies in World Christianity (Phan 2012: 183, Irvin 2016: 4). This contribution explores the dynamics and models of relating to 'the religious other' as developed within the World Council of Churches and the Vatican.

The global reach and size of the Roman Catholic Church (RCC), and the fact that the WCC includes not only historic Christian World Communions such as the Lutheran, Reformed and Anglican among others, but also much of Eastern Orthodoxy and now great blocs of African Independent Churches and Pentecostal and Evangelical Churches, means that between them the RCC and the WCC constitute the great majority of Christians at least in some formal sense of interconnected fellowship. This is arguably the case even though not all Christian communities are represented by this combined institutional expression of ecumenism constitutive of World Christianity.

Furthermore, it needs to be noted that at its inception the ecumenical movement embraced, first, the denominational diversity of Protestantism, and was soon joined by members of the diverse Orthodox family. It has since expanded to include many other 'Christian World Communions' and other ecclesial blocs, such as African Independent Churches. While at one level the Roman Catholic Church, by virtue of its own ecumenical openness-especially since Vatican II - may be, and most often is, included within the umbrella of ecumenism, it has never been, nor can it be, a full member of the World Council of Churches. This latter is the institutional expression of ecumenism, par excellence, though less than the sum of what might be regarded as representing 'World Christianity' in the Van Dusean sense.

To return now to the two interrelated organs of ecumenism, there is one major difference in modus operandi of these that needs to be noted. Whereas for the RCC there is centralised authority and the directive of a clear magisterium, for the wCC (being a council of churches) there can, at best, only ever be a modicum of consensus and, more likely, an advisory guideline that tends to be honoured more in the breach, if not simply ignored outright. For, with both the WCC and the RCC there are fault lines of theological difference-reactionary conservatisms, even countervailing fundamentalisms - that militate against any full and final unity of agreement and action. Nevertheless, many Catholics take cognisance of Vatican decrees and documents, and many churches of the wCC do pick-up on the agendas, resources, and programmatic foci of the WCC. Ecumenism, as with the very notion of global or World Christianity, is a work in progress. For although the world-wide Christian community may profess openness to the world at large and an inclusiveness of fellowship one with another, in reality the divides of theological self-understanding, as also the 
divides of ecclesial structures and other church organisational arrangements, can be devastatingly profound.

With all this in mind, how might the question of Christian relations with other faiths be addressed from a perspective of World Christianity? While it is true that today we can speak of Christianity as one among a number of recognisable world religions, the fact remains that no world religion is itself one unified 'thing'. All religions are marked by internal divides and variant identities. 'Christianity' does not relate with 'Islam', for example; rather specific Christians in concrete locales and times relate, positively or negatively, to or with specific Muslims is particular situations. Catholics may dialogue with Shi'a; Anglicans with Sunni. But even then, it is North Atlantic (UK/US) Catholics and Iranian Shi'a, and all at the scholarly level. And UK Anglicans dialogue with Egyptian Sunnis at the al-Azhar mosque and university. Dialogical and relational specificities come before generalised comment, discussion, or articulation of interreligious dialogue and interfaith relations per se. And whereas interreligious dialogue tends for the most part to be specific to bi-lateral engagements of a more formal type, interfaith relations tends now to refer to the prospect and reality of multi-faith engagements allowing for a greater range of interaction and common-ground community enhancing activities, such as interfaith councils representing a number of different religions whose communities of faith coexist within a given society. This chapter focusses on formal and representative developments of contemporary Christian engagement in interfaith relations, taking something of a case study approach in respect to the wCC and the RCC.

During the course of the 2oth century, Christian involvement in interreligious dialogue became, in effect, a permanent and formally endorsed ecclesial activity (Pratt 2010). Nevertheless, at times the eastern Orthodox churches within the WCC, and various conservative and evangelical churches, or reactionary constituencies within some other member churches of the wCC, have expressed resistance and objection. There would seem to be no going back, despite dissenting voices. The development and promotion of dialogical engagement through various initiatives involving the wCC, ${ }^{1}$ together with, since the early 196os, similar developments undertaken by the Roman Catholic Church, ${ }^{2}$ have been of critical importance. How did this come about? What has occurred down to the present time? Other religions and their peoples are viewed

1 Initially, this was via a programmatic 'Sub-unit on Dialogue with People of Other Faiths and Ideologies' (DFI), thence the 'Office on Inter-Religious Relations' (OIRR) and more recently the office or team for 'Inter-Religious Relations and Dialogue' (IRRD).

2 At first through the 'Secretariat for Non-Christians' (SNC) which became the 'Pontifical Council for Interreligious Dialogue' (PCID). 
today — at least formally — not so much in terms of competition and threat but as potential partner and actual neighbour. Leaders from other religions receive hospitable welcome at the Vatican; the religious 'other' is received as an honoured guest at wCC Assemblies. Where, previously, friendly and accommodating relational détente on the basis of mutual respect and regard would have been the exception, it is now the effective rule. Members of other religions join with Christians as interlocutors at dialogue conferences; as partners in interfaith organisations; and in common quests and cooperative ventures of one sort or another. What has taken Christianity worldwide, in and through its central ecclesial structures of the wCC and the Vatican, into dialogical engagement with other religions? In order to sketch an answer, we need to go back to the first decade of the 2oth century.

\section{$2 \quad$ Early Twentieth Century Ecumenical Developments}

The first large-scale international 'World Missionary Conference' was held in Edinburgh in June of 1910. Its work involved a number of commissions of which two were relevant to the eventual emergence of interreligious dialogical activities. These were Commission I, 'Carrying the Gospel to All the Non-Christian World' and Commission IV, 'The Missionary Message in Relation to the Non-Christian World'. Furthermore, this gathering gave birth to the International Missionary Council (IMC) which, during the course of the 2oth century, played a key role in Christian debates and development of interreligious dialogue. The second World Missionary Conference was held in Jerusalem at Easter in 1928 (Paton 1928). As at Edinburgh, the "issue of religious plurality, and the proper Christian response to it, received a great amount of attention" (Pranger 1994: 1). But it was the perception of a growth in secularism, or the secularist ideology, and the challenge which that posed for religion in general, and Christianity in particular, that constituted the main focus. This meeting, in recognizing non-Christian religions as valid systems of thought and faith marked a turning point in attitude toward them, with motifs of positive regard and appreciation of inherent values coming to the fore (Mott 1938). Secularism, as a challenge to all religion, was perceived to offer for Christians a point of contact with people of other religions, with the conference issuing a call for other religions to join with Christianity in the struggle against secularism. Although this was a controversial initiative, to be severely criticized only ten years later, it nevertheless prefigured one of the platforms of dialogical engagement that was to emerge several decades further on: working together in 
a common cause. Indeed, secularism, as a point of common cause with other faiths, was soon critiqued by Hendrik Kraemer (1930), among others, with his advocacy of revelation as the counterpoint to "secular corrosion".

At Jerusalem, Christian and non-Christian alike were seen to be in need of salvation: each shared equally in the human need of redemption, and the quest for justice and community, at least. Despite sharp points of theological disagreement, there was nonetheless a general inclination "to admit that other religions had spiritual values" which Christians could positively affirm: but certainly not salvation as such, of course; the uniqueness of Christ vis-àvis salvation was not up for debate (Sperber 200o; Cairns 1929). The conference message "spoke against any imperialistic attitude of Christians to other faiths ... (and made) use of the word 'sharing' for the act of Christian witness to those of other faiths" (Ariarajah 1991: 45). The stage was set "for a clear, concise, and considered Christian position in relation to people of other faiths" (ibid: 51), but the way ahead was not clear. Indeed, opposition was voiced to the call for dialogical engagement that the debates at Jerusalem 1928 had signalled (cf. Pranger 1994: 46). Ambiguity about interreligious dialogue can be said to have marked Christian engagement from the outset; the issue has ever been a polarising one.

At the 1938 meeting of the IMC held at Tambaram, India, the concept of other religions evincing positive spiritual values, as affirmed at Jerusalem a decade earlier, was maintained alongside the unassailable uniqueness of Christ - to which all other religious claims and values were, in the end, to be relativised (Addison 1938). This event was to become famous within the ecumenical movement as a moment at which relations with people of other faiths was curtailed relative to the openness and broad acceptance that had emerged thus far. An assertion of Christian uniqueness and superiority was made such that intercourse with any other faith tradition was correspondingly queried-if not negated-if it was other than evangelistic in modality and intent (Paton 1939). This derived largely, but by no means solely, and nor without opposition, from the work of the Dutch missionary theologian, Hendrik Kraemer (1938). He had a deep and positive appreciation for the cultural and value dimensions of other faiths, but this was not to be confused with the imperative of Christian salvific proclamation. The outcome, which was to remain highly influential until quite late into the 2oth century, was to popularise and extend the distinction between revelation, understood as divinely given through Christ alone, and religion per se - that is, all forms of human seeking-for-the-Divine. Tambaram affirmed both continuity and discontinuity: Christianity, qua religion, is indeed one of many; yet revelation in 
and through Christ sets Christianity apart from all religions, and indeed from religion as such.

\section{Mid-century Consolidation: The World Council of Churches}

Following World War II, the stalled ecumenical movement resumed its developmental trajectory. The first Assembly of the newly mandated wCC was held in Amsterdam in 1948 (Visser't Hooft 1986). The stage was now set for significant new issues such as relationships to other religions. However, other than a report and recommendations on the 'Christian Approach to the Jews', certainly a significant post-War focus (see Brockway et al. 1988: 5-9), the inaugural Assembly did not address directly the matter of relationship to other faiths; rather, evangelical witness predominated. Relationship to persons of other religions was to be primarily, if not solely, evangelistic and not dialogical. The uniqueness of Christ's lordship was affirmed over against any suggestion of relativism and syncretism (Ariarajah 1991: 95; Wilson 199o). The de facto stance towards other religions appeared unremittingly exclusivist. However, the second Assembly of the WCC, held in Evanston (USA) in 1954, saw some shift in ground towards a more inclusivist stance, and thereby an entirely new openness to other religions and the possibility of genuine dialogue (cf. Van der Bent 1991). A growing mood of respect toward other faiths became evident. The pre-War language of 'sharing' re-emerged.

In the ecumenical scene, newly emergent Asian Christian leadership promoted positive relating to other religions. Sharp questions were raised: "Must the attitude of the evangelist be that Christianity should supplant other religions? Or can it content itself with the conviction that Christianity is the fulfilment of other religions? Are there still further alternatives-those that hold that in Christ a transformation has taken place, or that in Christ all religions are brought under judgement?" (Ariarajah 1991: 99). An awareness of the widespread renaissance of other religions had come to the fore, particularly in missionary circles such as the IMC (cf. Newbigin 1959). Nevertheless, there was still an overriding Christocentrism and allied priority given to the missionary imperative in evidence (Fulton 1959). But the issue of establishing and pursuing an interactive relationship with other religions was gathering momentum nevertheless. The drive to engage seriously in interreligious dialogue was again underway.

In 1955 the wCC initiated a study programme entitled The Word of God and the Living Faiths of Men. This programme ran until 1971 and involved a number of Study Centres around the world together with a series of regional 
ecumenical consultations and allied reflection meetings. The obligation to witness - resulting in the need to clarify the relation of the gospel to other religions, together with emerging new opportunities and contexts for interreligious engagement and so the need for learning about the 'other' - constituted the fundamental rationale for the programme. Furthermore, such a study needed to be ecumenical because all churches were involved, whether directly or indirectly, and because the large and complex nature of the task required resources from throughout the world church. Significantly, in July 196o the programme was affirmed as being inclusive of Christian-Muslim dialogue specifically, with the final report underlining "the responsibility of Christians for meeting Muslims in a constructive way" (Sperber 2000: 8).

In many respects it was this programme that enabled interreligious dialogue to be taken up by ecumenical Christianity in a way never before possible. Indeed, its development signalled a growing responsiveness within the wCC, and also the wider global Christianity it represented, to the increasingly pressing demand for a serious and significant addressing of intercultural and interreligious relations and issues. The context of such concern was that of mid-2oth century post-war recovery, readjustments, and burgeoning new opportunities. The impact of contemporary globalising tendencies and dynamics was beginning to be felt. Improvements to mass-media enabling a more rapid and immediate exchange of information were well underway. The television age was dawning. And the increased and more widely-spread capacity for demographic shifts, through the ebbs and flows of migration, were stimulating ever more significant cultural and population encounters. Such factors either brought about changed circumstances in terms of the situations in which people lived, or else alerted the world to hitherto unacknowledged contexts-and thus to new issues to be tackled. Interreligious dialogue was not merely a theoretical option; it was an immediate existential demand. A key-note speaker at the 1961 wCC Assembly, Paul Devanandan, affirmed other faiths as manifesting responses to the creative activity of the Holy Spirit: "The only alternative is to confess either the Christian ignorance of God's ways with people or the Christian blindness in refusing to believe in God's redemptive work with people of other faiths" (Thomas 1987: 89).

It is at this juncture that new-indeed epoch-making-developments occur within the Roman Catholic Church that bring about not only a major development in respect to interreligious dialogue within this, the largest, Christian bloc; it also begins an era when hitherto Protestant and Orthodox ecumenical engagement in interreligious matters is expanded, in many contexts, to include Roman Catholic. 
The Roman Catholic Church (RCC) had been long content with the status quo of received tradition within which any modification was carefully contained. Acknowledgment of the 'religious other' - even other Christian Churcheswas, at best, muted (PCID 1994: 89). To the extent that encounter with another religion might be entertained, for whatever reason, the official response was one of considerable caution. Certainly, there was no salvific value accorded to other religions, and the notion of establishing some kind of dialogical relationship with any religious 'other' was a relatively fringe idea that had been at times pursued in some quarters, but always courted controversy. Up until the 196os religious exclusivism held unassailable sway. However, not long into his pontificate Pope John XXIII convened a great Council, 'Vatican II', comprising the bishops from throughout the worldwide RCC, which met at the Vatican for several sessions at different times from 1962 up to and including 1965. Concern for a reappraisal of the relation of the Church to the Jews had featured in the thinking of Pope John XXIII when he convened this Second Vatican Council. However, he died in June 1963 before the Council had concluded. His successor, Pope Paul vi, took up the reigns of papal office and saw the Council through to its ending, and it was under his leadership that significant innovations were undertaken (Abbott 1967). His 1964 encyclical, Ecclesiam Suam, sounded a note of respect for "the moral and spiritual values" of other religions, advocating openness to them "and a willingness for practical dialogical engagement", albeit within the framework of an apostolic mission (ES 1964, cl. $107-8) .{ }^{3}$ Nonetheless, dialogue was now seen as denoting "a whole new way of thinking, a way of seeing and reflecting on the world and its meaning" (Swidler 1990, xi; cf. Jadot 1983).

Throughout his pontificate Paul vi was both guided by and stamped his interpretive refinement on, the directives and pronouncements that emerged from the deliberations of the Second Vatican Council. And of the many documentary outcomes from this Council (see Gioia 1997; Hastings 1991; Sheard 1987; Nolan 2006), signalling quite remarkable changes, in a wide variety of areas of Church practice and doctrinal stance, there were some which both directly and indirectly paved the way for the engagement of the RCC in interreligious dialogue, including in particular dialogue with Jews and with Muslims. ${ }^{4}$

3 Note: this and other Vatican II documents are available of the Vatican website: see http:// www.vatican.va/archive/hist_councils/ii_vatican_council/index.htm.

4 These are: Nostra Aetate (NA), Lumen Gentium (LG), Dei Verbum (DV), Apostolicam Actuositatem (AA), Dignitatis Humanae (DH), Ad Gentes ( $A G$ ), and Gaudium et Spes (GS). 
The single most important of these, so far as interreligious dialogue is concerned, was Nostra Aetate, the 'Declaration on the relation of the Church to non-Christian religions'. This relatively short statement (only some 1200 words of text in its original Latin) was promulgated in 1965 and is divided into five sections, or chapters (Gioia 1997: 35-40). The first comprises an introduction in which the motif of the timeliness of "examining with greater care" the relationship of the Church to other religions, in the context of the commonality and transcendent unity of the human community which yet displays great religious diversity, sets the tone. This diversity is elaborated in the second section which makes mention, in particular, of Hinduism and Buddhism, and alludes to other religions more generally. Significantly, within this section there is found a pivotal passage which states:

The Catholic Church rejects nothing of what is true and holy in these religions. She has a high regard for the manner of life and conduct, the precepts and doctrines which, although differing in many ways from her own teaching, nevertheless often reflect a ray of that truth which enlightens all men.

NA cl. 5

Very clearly an attitude of openness to the 'other' is here signalled. However, this significant, if somewhat general, indication of relational regard is followed immediately by a delimiting statement: "Yet she proclaims and is duty bound to proclaim without fail, Christ who is 'the way, the truth, and the life' (John 14:6). In him, in whom God reconciled all things to himself (cf. 2 Co. 5:18-19), men find the fullness of their religious life" (NA cl. 5). Openness to other religions, wherein is urged "with prudence and charity ... discussion and collaboration with members of other religions", is not absolute; it is rather a relative stance that insists on a clear perspective of identity and mission whither the Church's openness to interreligious dialogue is to proceed. The third section focuses on Islam. It speaks of the Church's "high regard for the Muslims" and goes on to state:

They worship God, who is one, living and subsistent, merciful and almighty, the Creator of heaven and earth ... They strive to submit themselves without reserve to the hidden decrees of God, just as Abraham submitted himself to God's plan, to whose faith Muslims eagerly link their own. Although not acknowledging him as God, they venerate Jesus as a prophet, his Virgin Mother they also honour, and even at times devoutly invoke. Further, they await the day of judgement and the reward of God 
following the resurrection of the dead. For this reason they highly esteem an upright life and worship God, especially by way of prayer, alms-deeds and fasting.

NA cl. 7

Nothing is said about Islam as a religion, nor the status of the Qur'an as scripture or Muhammad as Prophet. However, Nostra Aetate (NA) acknowledges the "many quarrels and dissensions" that have obtained in the past between Christians and Muslims, yet seeks to go beyond that past and urges "that a sincere effort be made to achieve mutual understanding” (NA cl. 8).

The fourth section speaks at relative length of the relationship of the Church to Judaism. The essential Hebraic heritage of Christianity is acknowledged, going back to the indissoluble link with the patriarch Abraham. Furthermore, a reminder is given that Jesus and the Apostles were all Jews. On the basis of "a common spiritual heritage" the Vatican Council encouraged "mutual understanding and appreciation" (NA cl. 13). Significantly, $N A$ states unequivocally that

... neither all Jews indiscriminately at that time, nor Jews today, can be charged with the crimes committed during (Christ's) passion.... (Although) the Church is the new People of God, yet the Jews should not be spoken of as rejected or accursed.... Indeed, the Church reproves every form of persecution ... she deplores all hatreds, persecutions, displays of anti-Semitism levelled at any time or from any source against the Jews.

$N A$ cl. $14 \& 15$

$N A$ concludes with three short paragraphs that comprise its fifth sectionentitled 'Universal Fraternity' - so echoing the motif of the Introduction: the common bonds of humanity by virtue of being created by God. And it adds, as a contextual rider to the call for dialogical relationship as a primary modality of encounter with peoples of other faiths, the clear reprobation of any form of discrimination or harassment (NA cl. 19). At the time, NA may have occasioned some disappointment at what was left unsaid; but it nevertheless stands as a most significant document for what it did say. However, although $N A$ "recognizes a search for God in other religions and mentions dialogue and collaboration, no attempt is made to define it. It is set within the context of the search for human unity and the assumption that such unity finds it origin in creation and in Christ, to whom the Church is called to witness" (Gioia 1997: 248). Nevertheless, with Nostra Aetate the first formal step by the Church of Rome to genuine and mutual dialogue with other religions was taken; an open 
attitude to other faiths was clearly encouraged by the Second Vatican Council. But, as it happened, in this regard $N A$ is not the only relevant document.

Lumen Gentium ( $L G$ ), the 'Dogmatic Constitution on the Church', was issued in 1964, the year before $N A$, and it begins with an affirmation of the Church as the sacramental vehicle wherein humanity may attain "full unity in Christ" ( $L G$ cl. 1) in the context of the universality of the One People of God and, inter alia, the reconciling and in-drawing mission of the Catholic Church (LG cl.13). In this regard the salvific validity of other faiths, and especially that of Islam, is given high recognition: "the plan of salvation also includes those who acknowledge the Creator, in the first place among whom are the Muslims: these profess to hold the faith of Abraham, and together with us they adore the one, merciful God ..." ( $L G$ cl. 16). The explicit reference to Islam, by way of the inclusion of Muslims within the divine plan of salvation, is the first such documentary reference emanating from Vatican II: the scene was set for the development which then resulted in Nostra Aetate. Arguably, lying behind the impetus of the Roman Catholic Church to engage in interreligious dialogue was, at least in part, a new acceptance of religious plurality, albeit certainly not the (later) ideological stance of pluralism as a conceptual framework for comprehending and valuing that plurality, for such views were — and remain here- highly contentious, arousing much perplexity and polemical reaction.

A summary overview of lead theological rationales for dialogue, or components of a theology for dialogue, emerges from a consideration of the work of the WCC and the Vatican. These are socio-contextual, community-building, theocentric, responsive and salvific rationales. I do not claim this list as exhaustive; only that these reasons seem to stand out both in their own right and as illustrative of wider trends.

\subsection{Socio-contextual Rationales}

Socio-contextual reasons to engage in interreligious dialogue refer to wider contextual factors that can be seen to aid or indirectly promote the cause of dialogue. In the context of ecumenical engagement from the mid-2oth century that we are here considering, these include, for example, a post-war situation of openness toward, and positive regard for, other religions and cultures. There had been earlier intimations, as noted above, but it was the emerging globalising factors and post-war awakenings to religious and cultural 'others' as immediate neighbours that particularly contributed. This included a Christian 
affirmation of compatible values being able to be found in other religions, as well as affirming a more general value, or validity, of other religions: they, too, have their place in the greater scheme of things. And this positive regard of the fact and substance of other religions coincided, of course, with a growing affirmative response to, and concomitant regard for, the phenomenon of religious plurality - both inter and intra - as such. New appreciations and related new thinking were in the air. Indeed, it is quite clear that the context of increasing religious diversity - in some quarters at least (it needs to be remembered that in some parts of the world Christians were well used to living in a context of considerable religious diversity) — has been a longstanding component in the overall rationale for Christian engagement in interreligious dialogue and interfaith relations. Religious plurality, or the multi-faith diversity as the lived context of much Christianity throughout the world, continues even today as a principal element justifying the interreligious dialogical imperative by way of responding to that plurality.

Another broad socio-contextual component, emerging during the course of the 2oth century, was the impact of secularisation. Secularism, or rather the religious response to it, was one of the first 'common cause' issues articulated as providing good reason to engage in interreligious dialogue. Others can be added, particularly the quest for global peace and justice and, more recently, addressing inter-communal tensions, global environmental responsibilities, the worldwide economic recession and related issues, the HIV-Aids situation, as well as other social concerns. However, the perception of secularism as a common threat, or at least challenge, to religion as such arguably remains the case today, especially where secularism is expressed in terms of opposition to religion having a place in the public square. Contemporary interfaith dynamics often see diverse religions joining forces in some way to resist or ameliorate the impact upon their communities of a hostile secular society. This element of joining forces in the face of a common threat brings us to the next groupingcommunity-building rationales for dialogue.

\subsection{Community-building Rationales}

The quest for community, in both localised and global senses, can also be seen as a clearly argued rationale for dialogue. A necessary connection between the Christian community and other faith communities was clearly given in the promotion of 'dialogue in community' (Sperber 2000: 14; Samartha 1977; WCC 1977; Best 199o). For example, Pope John Paul II regarded dialogue as the modality par excellence for engaging in the quest for improved human community: the engendering of mutual respect; the tackling together of common human problems; promoting the socio-political task of nation-building. 
Motifs of human solidarity and human community, and the related promotional quest, are long-standing elements of a Catholic rationale for interreligious dialogue (Humbertclaude 1969; Zago 1984; Arinze 1987; Fitzgerald 1988; PCID 1994). Indeed, from the very outset the fundamental purpose of dialogue was here articulated in terms of the 'social good' of humanity. The corollary requirements were that of mutual learning-hence educational efforts within the Churches - and an intentional engagement at many levels: interreligious dialogue, at the very least, serves the cause of social justice and healthy community relations and requires the discharge of an educational task. Also, from the early 199os, the wCC tended to focus, for a time at least, on the fostering of inter-faith and allied inter-communal relations, especially in respect to situations of conflict (VanElderen 1998; Kinnamon 1991). In effect, the lead rationale for engagement in dialogue had by this stage become diaconal: dialogue in the service of a greater communal end. This was given graphic exemplification by a 1994 interreligious team visit to Fiji (Ucko 1994). Apart from the specific outcomes achieved, it was observed that the success of such a visit, "comprised of people of different faiths, travelling and working together, having the same objective in mind as a common agenda", could well provide a model of interreligious co-operative work for the future. Service to the wider community is justification for-indeed in many instances, such as the Fijian situation, even requires-interreligious dialogical engagement.

\subsection{Theocentric Rationales}

Recognition of the one universal Creator responsible for the whole of creation in all its fullness and diversity can be said to be a consistent element of theological rationale for dialogue: we are all equally creatures of the same one Creator. This rationale was early-on articulated in terms of the concern of God for all creation, the universal application of the divine love, and "the universality of the Christ who died for all and the eschatological expectation of the rule and reign of the Kingdom of God as fully encompassing of human diversity, including religion and culture" (Van der Bent 1986: 46). The idea of the encompassing love of God has often been advocated as a theological rationale for dialogue (WCC 1987). A theology for dialogue would clearly have the motifs of God as Creator and Sustainer to the fore. The affirmation of the unity of the human race as a creation of God is an allied rationale for dialogue: all of humanity shares a common divine origin. This impetus and rationale for interreligious dialogue is very much an expression of "God's concern for all: the divine love and salvific purpose is universal" (Van der Bent 1986: 46). This love is of universal scope; all are included. It comprises the greatest challenge to Christian praxis, for even those who are deemed 'enemy' are subject to the 
commandment to 'love the neighbour'. And this universality is itself also an expression of the idea encapsulated in the notion of the seeds of the Word (Logos) of God that are seminal across creation.

The final element is that of belief in God as Trinity. It is faith in the Triune God, who calls Christians to human relationship with their many neighbours and this adds weight to the rationale for dialogue. This relationship is marked by listening and speaking: in both attending to the other, and also bearing witness to the self, are dialogue and proclamation properly and in a balanced way equally involved (wCC 1979). Indeed, one principal reason to engage in interreligious dialogue is because of Trinitarian relationality: the universality and encompassing pervasiveness of the love of God the Father; the enlightening Word and Wisdom given in and through God the Son; and the regenerative lifegiving Spirit that "acts in the depth of people's consciences and accompanies them on the secret path of hearts toward the truth" (ACTFOR 1984: cl. 24. Cf. Hinze 2006; Sheard 1987:246-251). Dialogue is regarded as a genuine give-andtake of insight and understanding premised on Trinitarian relationality.

\subsection{Responsive Rationales}

The Catechism of the Catholic Church (2000), first issued in 1992, gives a broad rationale for interreligious dialogue premised on notions of the innate human hunger for relationship with the Divine: the universality and commonality of the inherent human quest found within the variety of religions throughout history. This relates to the 'Seed of the Word' motif together with a universal 'moral sense' understood as being present within the diversity of human cultures and religions found throughout the entire world. It also allows for a measure of validity and veracity being attributed to non-Christian religions, so providing a further basis on which to pursue dialogue. At the same time there is a pneumatological implication: the ubiquitous efficacy of the Holy Spirit is understood to be operative at the very heart of being human. Thus, being open to the other in dialogue is a modality of being open to the God who is present in, with, and through the other: the pneumatological gives way to theological anthropology - each person "grows by encountering and sharing with others" whereby seeking after truth "is better attained, understood, and lived through encounter, and by it even one's own faith can be purified and deepened" (Zago 1984: 267). Anthropological foundations of interreligious dialogue can be found also in respect to the deepening and enriching of faith and in the humanising and improving elements of social interaction (cf. Jukko 2007: 243-246).

\subsection{Salvific Rationales}

The purpose of dialogue is not just a matter of co-existence. A deeper theological relationality between Christians and people of other faiths is being 
sought: a Christian concern for a theology of religions that would embrace the question of God's plan for salvation for all-including those of other faiths-in contrast to engaging in dialogue with the intention, in the end, of incorporating the 'other' into the Christian fold of faith as the sole efficacious means of obtaining salvation. The assertion that God, the Creator of all, is present and active in the very plurality of religions is understood to lead inexorably to the inconceivability that the divine saving activity could be confined to any one continent, cultural type, or groups of peoples. Redemption is inherently universal. The singularity of creation and the universality of redemption are drawn upon, implicitly at least, as part of the supporting rationale for interreligious dialogue. Most typically it is accompanied by the specifically Christocentric and exclusive affirmation that it is only in and through Christ that the fullness of the religious life can be found. Yet there is also an inclusive dimension: all of humanity shares a common divine origin and eschatological orientation (Arinze 1987: 254). Christocentric affirmation does not necessarily have to result in theological exclusivism. Either way, however, it is the implication of belief in the universality of the redeeming Creator that can be said to be a distinctive theological rationale for dialogue. Furthermore, the motif of "the universality of the Christ who died for all", together with "the eschatological expectation of the rule and reign of the Kingdom of God as fully encompassing of human diversity, including religion and culture" (Arinze 1987: 254; cf. Van der Bent 1986: 46; Kinnamon 1991; Fitzgerald 1994), yield yet another basis for dialogue. ${ }^{5}$

Further, and especially from a Roman Catholic perspective, dialogue carries with it a soteriological dimension: "God, in an age-long dialogue, has offered and continues to offer salvation to humankind. In faithfulness to the divine initiative, the Church too must enter into a dialogue of salvation with all" (DP 1991: c. 38). John Paul II declared that, with respect to "the economy of salvation, the Church sees no conflict between proclaiming Christ and engaging in interreligious dialogue" (RM 1990: cl. 55). These two elements, which are essential to the overall task of mission, are distinct and non-interchangeable, but are symbiotically interconnected necessarily. Interreligious dialogue "is witness to Christ. It is dialogue of salvation. It is part of the total mission of the Church" (Arinze 1987:256). Dialogue is not just juxtaposed with proclamation; it serves, in the end, the greater cause of Christian witness. Interreligious dialogue is

5 Such sentiments are found in reports, often unpublished, such as the wCC 'Report of the Kandy Consultation, Feb 27-March 5, 1967'; the 'From Baar I to Baar II: A report from a consultation on the theological significance of other faiths' found in Current Dialogue, Vol 26 (June 199): 1-68; the Vatican's Lumen Gentium and Nostra Aetate (see Gioia 1997). See further in Pratt 2010. 
understood to accompany mission on account of the soteriological imperative of the gospel.

\section{6}

\section{Models of Dialogue}

It is significant that, at the official level of policy pronouncements and practical guidelines the WCC and the Vatican, if not speaking with one voice exactly, are certainly singing from the same hymn-sheet. Models employed in the approach to interreligious dialogue have been different, but arguably complementary.

\section{1 wec Models}

Three models of dialogue have applied in respect to the wCC which I identify as systemic, communitarian, and relational. They are fairly obvious, and require but relatively brief adumbration. It also needs to be said that they are not mutually exclusive, although each has had a period of predominance in terms of the practice of dialogical engagement. In certain contexts the very nature of the dialogical agenda could involve two or more of these models simultaneously.

\subsection{Systemic Dialogue}

Systemic dialogue refers to the notion of dialogue as a discursive interaction between belief-systems, mediated through the meeting of minds. Although it is persons who dialogue, here the focus is not the relationship per se that obtains between and among the interlocutors; rather on the doctrines, teachings, and other authoritative statements and expressions of belief and worldview as espoused by the religious traditions that the interlocutors represent and/or belong to. This is the arena of discussion, enquiry, and debate undertaken by expert representatives. In some ways this is the classic understanding of what dialogue is about: an intellectual exercise and quest. Although it was perhaps one of the earlier models employed, it was eventually eschewed by the WCC in favour of the communitarian and relational models on the basis that dialogue is primarily an interpersonal engagement in respect to addressing concrete social issues. Inter-systemic dialogue was dismissed as an abstract arid exercise, effectively the antithesis of genuine dialogue, for dialogue was soon understood to be primarily, if not solely, a relational experience; a meeting of persons of different faiths, set within a context of various lived community engagements. 


\subsection{Communitarian Dialogue}

This second model emerged very much in the context of the communitybuilding rationale for dialogue. Dialogical engagement is here regarded as a modality of community building per se in which, although also an interpersonal exercise, the agenda was that of a societal enhancing nature: the quest for peace; the promotion of harmony; the agitation for justice; the combating of social ills; and so on. This soon emerged as the predominant model of wCC-related interfaith initiatives and dialogical engagements. It was attractive because of its pragmatic orientation, and because it allowed for relatively clear identifiable and measurable outcomes. Although having high aims the underlying issue of the applied meanings of concepts such as justice, rights, 'the communal good', and so forth could prove problematic, and eventually contributed to a recognition that even such pragmatic-focussed dialogue requires a measure also of systemic (theological, meaning-probing) dialogue. In large measure much communitarian dialogue could be critiqued as amounting to an exercise in social engagement, as opposed to an exercise of deep intercommunal understanding through dialogue. It also meant that underlying thorny issues of an ideological and/or theological nature could be glossed over-but not entirely so-, for there is ever an educational dimension that wCC work is inclined to address, and this leads us to the third model.

\subsection{Relational Dialogue}

The relational model is enacted where dialogue is promoted on broadly educational grounds: mutual enrichment, deepened understanding, the need to combat ignorance and prejudice, together with the aim of building interpersonal relations of goodwill, especially among religious and community leaders. In many ways this could be seen as an extension or development of the communitarian model of dialogue. But here there is also the internal dimension of promoting intra-faith dialogue about interfaith engagement: encouraging and enabling Christian communities to learn about their religious neighbours and themselves and to reflect upon the theology of the religious 'other' per se. Arguably the relational model of dialogue, with its two-fold focus (self-directed and other-directed), is theoretically, if not also practically, a prior requisite to the communitarian model. In order to undertake interfaith engagement successfully as a community enhancing activity, there needs necessarily to be a foundation laid of relationship-building and mutual acceptance, and so a measure of mutual understanding. This must be attended to first. However, to what degree this happens in practice is moot. Where there is resistance to the idea of systemic dialogue, and a presupposition that it is that which forms the agenda 
of interfaith relational engagement, it is likely that the benefits of the relational model are short-circuited in favour of engaging the communitarian model directly. Programmes that draw multi-faith, or bilateral, communities together in a common project tend to gain more popular support with respect to WCC priorities and wider constituent Church endorsement. As a rule, Christians are good at loving their neighbours, but not necessarily at getting to know them at depth—let alone accepting them unconditionally.

\subsection{Vatican Models}

It was primarily through Catholic developments that the now standard fourfold model for dialogical engagement-Life, Action, Experience and Discoursewas articulated (Michel 1981; ACTFOR 1984; Arinze 1987, 1991; RM 1990). I suggest other distinctive models may be discerned also. The RCC, through the Vatican State, engages in formal diplomatic relations with the nations of the world. As an official Vatican organisation, the contacts which the Pontifical Council for Interreligious Dialogue (PCID) has with the world of other faith communities tend to be at high social and/or governmental level (Jukko 2007). The dialogue in which it is engaged is often between leaders. At the same time, the task of interreligious dialogue is a mandated work of the Church at large, supported and nurtured by the Vatican, particularly in and through its interreligious Dicastery, to which has been given "the apostolate of promoting dialogue with the followers of other religions ... and contributing to the formation of people who engage in interreligious dialogue" (Arinze 1993: 17). Wherever there is dialogue, there is also proclamation: the mission of salvific proclamation forms the default horizon within which, for the most part, dialogue takes place. So it is that, within these contexts, three distinct and mutually interactive models of interreligious dialogical engagement may be identified: ambassadorial, propaedeutic and humanitarian. These may also be seen to mark emphases or stages — or denote types — of dialogical engagement.

\subsection{Ambassadorial Dialogue}

In the first place can be found ambassadorial dialogue for the Vatican is a sovereign state with all the diplomatic responsibilities and relationships that pertain thereto. This is not to be underestimated. It influences the means of engagement and relating to any 'other' as such. Today many countries have ambassadors accredited to the Holy See, and in turn the Vatican has ambassadorial representation and relationships around the globe. So, it should not be surprising that this relational modality is found to the fore in respect of interreligious relations. In many situations, of course, state and religious relations coincide. A mark of the ambassadorial mode is that steps are taken to 
maintain long-term relationships: specific dialogical events may be themselves ad hoc, infrequent, and irregular; but the relationship between dialogical parties can be nurtured over time nonetheless. The annual goodwill message to Muslims throughout the world marking Eid al-Fitr, the end of the fasting month of Ramadan, may serve as an example. Over the years there has been a steady increase in reciprocal greetings "and expressions of gratitude" by way of response (Arinze 1997: 29). Since 1995 similar annual messages have been sent to Hindus, in respect of Diwali, and to Buddhists in respect of Vesakh. In the ambassadorial mode of dialogical relationship there is—or, at least, there is a presumption of - an encounter of equals: the establishment and maintenance of cordial and functional working relations is the order of the day. In this context the undergirding task is the patient and mutual self-presentation of one side to the other in the interest of fostering mutual authentic knowledge and respect. Ambassadorial dialogue is the implicit precondition for any dialogue of action: cooperative ventures require, in the first place, a context of mutual respect and functional communication. To that extent ambassadorial dialogue does not just name a type of dialogue that applies specifically to the role and work of the Vatican, but names a model that has wider applicability for the Roman Catholic Church, for in dialogue all Catholics anywhere, when acting as representatives of their Church, may well utilise this model vis-à-vis the commencement of a dialogue process, at least. And, qua model, it is not limited to Roman Catholic usage: it is one form of Christian dialogical modality that, arguably, could and has been applied by Christians in other contexts.

\subsection{Propaedeutic Dialogue}

The second model refers to the style, or dimension, of interreligious engagement that goes beyond the ambassadorial presenting of credentials to the careful explanation of the self to the other as a means of preparing the ground for further development and deepening of relationship. This allows for mutual invitation and responsive engagement. As with the ambassadorial model, it is premised on the reciprocities and protocols of the host-guest relationship paradigm. It is thus a model for dialogical engagement that, born of initial Vatican practice, informs the wider RCC work in this field. Inherent in this model is the fact that much careful attention is paid to identity explanation. This involves articulating an apologia and bearing clear witness, rather than simply a cursory informative self-presentation. Pains are taken to assert and explain what it means to be Christian - indeed, to be Catholic - in the context of this dimension of engagement. References to it abound with the language of 'proclamation', 'mission', or 'outreach'. Indeed, it is referred to in terms of clearing the way for appropriate evangelical 'invitation and witness'. Cardinal 
Arinze, in this regard, spoke of a 'conversion' that is concomitant to, if not inherent within, interreligious dialogue. There is, he wrote,

... a sense in which we can rightly speak of conversion as a needed mental state and as a result of dialogue. It is the sense of greater conversion to God. Every believer who meets other believers in interreligious contact should strive to be more and more open to the action of God. God can speak to us through our encounter with other believers. Such can become occasions in which we are challenged to become more faithful to the deeper calls of our faith

Arinze 1993: 41

Given that religion should be proposed, not imposed, the propaedeutic dialogue model is undoubtedly a valid form of interreligious engagement, one that is premised on both respecting the integrity of the 'other' and upholding one's own assertions and truth references.

\subsection{Humanitarian Dialogue}

The third Vatican-originating model may be called humanitarian dialogue. This can be discerned, in particular, in terms of the dialogue of action, where engagement is not so much in attending to issues of identity, relationship and understanding - such as would be expected in the context of dialogues of discourse and religious experience, and implied within the dialogue of life-but rather a coming together of two or more parties in the quest for a common goal, or the commitment to joint action for the greater good of the human community, whether in a local or wider context. Such dialogue, more particularly, is an expression of the local or regional church in action. This model approximates, arguably, the communitarian model of the WCC, but the wider context is somewhat different. A number of PCID-sponsored dialogues, such as the conference on Jerusalem or various consultations on the Middle East have focussed on socio-political issues and allied humanitarian concerns involving questions of justice, human rights, freedom and so on (PCID 1984; Zago 1984; Gioia 1997: 112-13, 426-28 502-4, 521-22; Pratt 2010). The humanitarian model stands alongside, and may even intertwine with, the propaedeutic and ambassadorial models.

It is the work of the Vatican which, as mentioned, has produced and articulated the four-often effectively regarded as standard-models of dialogue: life, whereby dialogical engagement is an epiphenomenon of everyday interactions; action, where dialogical engagement in respect to achieving a common goal or purpose in respect to the wider social good is enjoined, but without 
presupposing religious interaction per se; and the dialogue of experience that encompasses either an intentional communal inter- or multi-religious act, such as praying for world peace, or responding in a liturgical fashion to a communal disaster or other notable event, or else it refers-indeed more typically-to religious or spiritual exchanges such that interlocutors experience first-hand the deeper dimensions of one another's religious life; and finally discourse, wherein representative intellectual experts meet for in-depth conversation and discussion.

\section{7}

\section{Conclusion}

There is often a disjunction between official positions and policies of Churches at a global or regional level and what occurs locally in specific contexts. Nonetheless, where interreligious or interfaith engagement has been occurring locally this has often been in light of the 'permission-granting' policy and guidance from central Church authorities. In these situations, recourse to supportive ecclesial mandate can be significant and important. For, to be sure, within the RCC as well as member churches of the WCC there are those who simply choose to ignore issues of interreligious dialogue or interfaith relations. And if this is so for 'ecumenical Christianity' it is also the case more widely within Christianity.

The impetus for Christian engagement in interreligious dialogue and interfaith relations has come from two directions: local contexts where Christians daily interact with people of other faiths, and from usually some central reflection on the meaning and implications of that for wider Christian selfunderstanding and contemporary missionary endeavour (cf. WCC 2016). There is ever a dialectical tension between a desire for dialogue between religions as complex systems of belief and thought for the purposes of seeking and deepening theological understanding on the one hand, and recognition of the priority and importance of relationships between persons of different faiths for the purposes of social peace and harmony, and working together for a greater common good. Both the Vatican and the WCC took the first route in the early days of opening up to interreligious dialogue. But by the late 2oth century a turn towards engaging in relationship between peoples of different faiths, in light of local specific contexts and the multiplicity of religious identities and orientations that exist within religions, all but eclipsed discursive theological dialogue. Arguably both are needed, with interfaith relations the arena of practical lived engagement and interreligious dialogue as the point where that engagement is reflected upon and discussed in light of religious beliefs, 
values and principles, and where interlocutors may mutually interrogate each other about those; and specific Christian reflection to produce a theology—or theologies - of religion whereby Christian belief and thought may appropriately adjust to, and formulate appropriate positions on, the very context of religious diversity whence arises the fact of engagement with religious 'others' in the first place. This study of these multiple ways of relating to the religious other should constitute a key feature of a World Christianity approach.

\section{Bibliography}

Abbott, Walter M.S.J., ed. (1967). The Documents of Vatican II. London: Geoffrey Chapman.

ACTFOR (1984). Attitude of the Church to Followers of Other Religions. Vatican City: Document of the Secretariat for Non-Christians.

Addison, James Thayer (1938). 'The Changing Attitude toward non-Christian Religions.' International Review of Mission 27,1:110-121.

Ariarajah, S. Wesley. (1991). Hindus and Christians. A Century of Protestant Ecumenical Thought. Amsterdam: Rodopi.

Arinze, Francis (1987). 'Interreligious Dialogue. Problems, Prospects and Possibilities.' Bulletin 66 (XXII/3): 247-265.

Arinze, Francis (1993). 'Meeting Other Believers. Introduction to the Plenary Assembly 1992.' Bulletin 82 (XXVIII/1): 17-22.

Arinze, Francis (1997). Meeting Other Believers. Herefordshire, UK: Gracewing.

Bent, Ans J. van der (1986). Vital Ecumenical Concerns. Sixteen Documentary Surveys. Geneva: World Council of Churches.

Bent, Ans J. van der (1991). 'WCC Assemblies.' In Nicholas Lossky, ed. Dictionary of the Ecumenical Movement. Geneva: WCC Publications: 1091-92.

Best, Thomas F., ed. (1990). Vancouver to Canberra 1983-1990. Report of the Central Committee of the World Council of Churches to the Seventh Assembly. Geneva: WCC Publications.

Brockway, Allan R. et al., eds (1988). The Theology of the Churches and the Jewish People. Statements by the World Council of Churches and its Member Churches. Geneva: WCC Publications.

Cabrita, Joel and David Maxwell (2017). 'Introduction. Relocating World Christianity.' In Joel Cabrita, David Maxwell and Emma Wild-Wood, eds. Relocating World Christianity. Interdisciplinary Studies in Universal and Local Expressions of the Christian Faith. Leiden: Brill: 1-44.

Cairns, D.S. (1929). 'The Christian Message. A Comparison of Thought in 1910 and 1928.' International Review of Mission 18,3: 321-331. 
Catechism of the Catholic Church. Revised in Accordance with the Official Latin Text Promulgated by Pope John Paul II (200o). Vatican City: Libreria Editrice Vaticana (2nd edition).

Dialogue and Proclamation. Reflections and Orientations on Interreligious Dialogue and the Proclamation of the Gospel of Jesus Christ (May 19, 1991).

Ecclesiam Suam (August 6, 1964)

Fitzgerald, Michael (1988). 'Mission and Dialogue. Reflections in the Light of Assisi 1986.' Bulletin 68 (XXIII/2): 113-120.

Fitzgerald, Michael (1993). 'Dialogue and Proclamation.' Bulletin 82 (XXIII/1): 23-33.

Fitzgerald, Michael (1994). 'Other Religions in the Catechism of the Catholic Church.' Pro Dialogo 85-86: 165-177.

Fulton, Austin (1959). 'The Missionary Nature of the Church. Reflections on the Christian Faith and Other Religions.' International Review of Mission 48,4: 389-397.

Gioia, Francesco, ed. (1997). Interreligious Dialogue. The Official Teaching of the Catholic Church (1963-1995). Boston: Pauline Books and Media/Pontifical Council for Interreligious Dialogue.

Jadot, Jean (1983). 'The Growth in Roman Catholic Commitment to Interreligious Dialogue since Vatican II.'Bulletin 54 (XVIII/3): 205-220.

Hastings, Adrian, ed. (1991). Modern Catholicism. Vatican II and After. London: SPCK, New York: Oxford University Press.

Hinze, Bradford E. (2006). Practices of Dialogue in the Roman Catholic Church. London: Continuum.

Humbertclaude, Pierre (1969). 'Clarification of the Nature and Role of the Secretariat for Non-Christians.' Bulletin 11: 76-96.

Irvin, Dale (2016). 'What is World Christianity?' In Jonathan Y. Tan and Ahn Q. Tran, eds. World Christianity. Perspectives and Insights. Essays in Honor of Peter C. Phan. Maryknoll NY: Orbis Books: $3-26$.

Jukko, Risto. 2007. The Trinity in Unity in Christian-Muslim Relations. The Work of the Pontifical Council for Interreligious Dialogue. Leiden: Brill.

Kinnamon, Michael, ed. (1991). Signs of the Spirit. Official Report, Seventh Assembly, Canberra, Australia, 7-20 February, 1991. Geneva: wCC Publications / Grand Rapids: Wm. B. Eerdmans.

Kraemer, Hendrik (1930). 'Christianity and Secularism.' International Review of Mission 19,2: $195^{-208 .}$

Kraemer, Hendrik (1938). The Christian Message in a Non-Christian World. London, Edinburgh House Press.

Michel, Tom S.J. (1981). 'Education for dialogue.' Bulletin 48 (XVI/3): 243-249.

Mott, John R. (1938). 'At Edinburgh, Jerusalem and Madras.' International Review of Mission 27,3: 297-320. 
Newbigin, Lesslie (1959). 'The Summons the Christian Mission Today.' International Review of Mission 48,2: 177-189.

Nolan, Ann M. (2006). A Privileged Moment. Dialogue in the Language of the Second Vatican Council 1962-1965. Bern: Peter Lang.

Paton, William (1928). 'The Jerusalem Meeting of the International Missionary Council.' International Review of Missions 17,1: 3-10.

Paton, William (1939). 'The Meeting of the International Missionary Council at Tambaram, Madras.' International Review of Mission 28,2: 161-173.

Pontifical Council for Interreligious Dialogue [PCID] (1994). Recognize the Spiritual Bonds which Unite Us. 16 years of Christian-Muslim dialogue. Vatican City: Pontifical Council for Interreligious Dialogue.

Phan, Peter C. (2012). 'World Christianity. Its Implications for History, Religious Studies and Theology'. Horizons 39,2: 171-188.

Pranger, Jan Hendrik (1994). Dialogue In Discussion. The World Council of Churches and the Challenge of Religious Plurality between 1967 and 1979. Utrecht/Leiden: IImo Research Publication 38.

Pratt, Douglas (2010). The Church and Other Faiths. The World Council of Churches, the Vatican, and Interreligious Dialogue. Bern: Peter Lang.

RM 199o. Redemptoris Missio (Vatican City: John Paul II, Encyclical).

Robert, Dana (2009). Christian Mission. How Christianity Became a World Religion. Oxford: Wiley-Blackwell.

Samartha, Stanley J. ed. (1977), Faith in the Midst of Faiths. Reflections on Dialogue in Community. Geneva: wcc Publications.

Sheard, Robert B. (1987). Interreligious Dialogue in the Catholic Church since Vatican II. An Historical and Theological Study. New York: The Edwin Mellen Press.

Sperber, Jutta (200o). Christians and Muslims. The Dialogue Activities of the World Council of Churches and Their Theological Foundation. Berlin \& New York: De Gruyter.

Swidler, Leonard (1990). After the Absolute. The Dialogical Future of Religious Reflection. Minneapolis: Fortress Press.

Thomas, M.M. (1987). Risking Christ for Christ's Sake. Towards an Ecumenical Theology of Pluralism. Geneva: wcc Publications.

Ucko, Hans (1994). 'Interreligious Team Visit to Fiji.' Current Dialogue 27: 2-14.

VanElderen, Marlin (1998). From Canberra to Harare. An Illustrated Account of the Life of the World Council of Churches 1991-1998. Geneva: WCC.

Visser't Hooft, Willem A. (1986). 'The Genesis of the World Council of Churches.' In Ruth Rouse and Stephen Neill, eds. A History of the Ecumenical Movement, 1517-1948. Geneva: World Council of Churches: 697-724 (3rd edition).

wCC (1977). Dialogue in Community. Statements and Reports of a Theological Consultation, Chiang Mai, Thailand, 18-27 April 1977. Geneva: wCC Publications. 
WCC (1979). Guidelines on Dialogue with People of Living Faiths and Ideologies. Geneva: wCC Publications.

wCC (1987). My Neighbour's Faith and Mine. Theological Discoveries Through Interfaith Dialogue. A Study Guide Geneva: wcC Publications.

wCC (2016). Who Do We Say That We Are Christian Identity in a Multi-Religious World. Geneva: wcc Publications.

Wilson, Frederick R., ed. (1990). The San Antonio Report. Geneva: wCC Publications. Zago, Marcello (1984). 'Dialogue in the Mission of the Church.' Bulletin 57 (XIX/3): $265^{-269 .}$ 